\title{
PENGARUH MEDIA LKS BERBASIS MODEL TAKE AND GIVE TERHADAP HASIL BELAJAR IPA SISWA KELAS V SD NEGERI JABUNG 01 KEC.JABUNG KAB.MALANG
}

\author{
Rizky Nadya Prabawati ${ }^{1}$, Erna Yayuk ${ }^{2}$, Kuncahyono $^{3}$ \\ Pendidikan Guru Sekolah Dasar, Universitas Muhammadiyah Malang \\ e-mail: kinadkinad40@gmail.com
}

\begin{abstract}
The existence of students' Natural Science worksheets use as a media for doing exercises and being sources all at once. Uneffective tool of study for users, because of an incomplete material in students worksheets. This research aims to discover the impact of students worksheet media with take and give basis to natural science study results on fifth grade students in SD Negeri 1 Jabung, Jabung subdistrict Malang regency, and the total amount of the effect using students worksheet with take and give based model. This study used quantitative research approach and the type of this study was experimental study with true experimental design. The sample collection technique was simple random sampling. As a data population, the researcher choosen $\mathrm{V}$ grades students of SDN 1 Jabung, Jabung subdistrict, Malang regency with academic year of 2016/2017 amounted to 44 students. As an experimental class, the researcher choosen VB class as much as 23 students and VA class as a control class with the total students as much as 21 students. The result of the study shown that (1) in the hypothesis test which use t-test, the result is 0.032 with the significance $5 \%$. It can be seen that the significant value (2-tailed) $<0,05$ means that Ho is rejected and Ha is accepted. (2) the total amount of the effect using students worksheet with take and give based model toward the result of IPA (Natural Science) study had a significant influece as much as $47,9 \%$.
\end{abstract}

Keywords: Effect, student worksheet, Take and Give, IPA (Natural Science) study result

\begin{abstract}
Abstrak: Keberadaan LKS IPA digunakan sebagai media untuk mengerjakan soal sekaligus sebagai sumber belajar. Penggunaannya masih belum efektif sebagai sarana pembelajaran, karena materi yang terdapat dalam LKS dirasa belum lengkap. Penelitian ini bertujuan untuk mengetahui pengaruh media LKS berbasis model take and give terhadap hasil belajar IPA siswa kelas V SD Negeri Jabung 1 Kec.Jabung Kab.Malang, dan besar pengaruh penggunaan media LKS berbasis model take and give. Penelitian ini menggunakan pendekatan penelitian kuantitatif dan jenis penelitian eksperimen dengan desain true experimental design. Teknik pengambilan sampel menggunakan simple random sampling . Sebagai populasi data, dipilih siswa kelas V SD Negeri Jabung 1 Kec.Jabung Kab.Malang tahun ajaran 2016/2017 yang berjumlah 44. Yang terpilih menjadi kelas eksperimen yaitu kelas VB dengan jumlah 23 siswa dan kelas kontrol yaitu kelas VA dengan jumlah 21 siswa. Hasil penelitian menunujukkan (1) pada uji hipotesis yang menggunakan uji t, hasilnya sebesar 0,032 dengan taraf signifikan 5\%. Terlihat bahwa nilai Sig.(2-tailed) $<0,05$ sehingga Ho ditolak dan Ha diterima. (2) besar pengaruh penggunaan LKS berbasis model take and give terhadap hasil belajar IPA memberikan kontribusi sebesar 47,9\%.
\end{abstract}

Kata Kunci: Pengaruh, Lembar Kerja Siswa (LKS), Take and Give, Hasil Belajar IPA

\section{PENDAHULUAN}

Ilmu Pengetahuan Alam (IPA) merupakan cabang pengetahuan yang berawal dari objek dan fenomena alam yang diperoleh dari hasil pemikiran dan penyelidikan ilmuwan yang dilakukan dengan keterampilan berkesperimen dengan menggunakan metode ilmiah. Hal ini sejalan dengan Kurikulum KTSP (Depdiknas, 2006) bahwa "IPA berhubungan dengan cara mencari tahu tentang alam secara sistematis, sehingga bukan hanya penguasaan kumpulan pengetahuan yang berupa fakta, konsep, atau prinsip saja tetapi juga merupakan suatu proses penemuan." Menurut Martinis (2009:78) menyebutkan bahwa keterampilan dasar dalam pendekatan proses adalah observasi, menghitung, mengukur, mengklasifikasi dan membuat hipotesis. 
Dapat disimpulkan bahwa keterampilan proses dalam pembelajaran IPA di SD meliputi keterampilan dasar dan ketrampilan terintegrasi. Kedua keterampilan ini dapat melatih siswa untuk menemukan dan menyelesaikan masalah secara ilmiah untuk menghasilkan produk - produk IPA yaitu fakta, konsep, generalisasi, hukum, dan teori- teori baru. Sehingga perlu diciptakan kondisi pembelajaran IPA SD yang dapat mendorong siswa untuk aktif dan ingin tahu.

Menurut Sanjaya (2009:24), salah satu kecenderungan yang sering dilupakan, bahwa hakikat pembelajaran adalah belajarnya siswa dan bukan mengajarnya guru. Sehingga dalam proses pembelajaran guru tidak hanya berperan sebagai model atau teladan bagi siswa, tetapi juga sebagai pengelola pembelajaran, guru berperan dalam menciptakan iklim belajar yang memungkinkan siswa dapat belajar dengan nyaman. Uno (2011:75) menyatakan "keberhasilan pencapaian kompetensi bergantung pada beberapa aspek. Salah satu aspek yang sangat mempengaruhi adalah bagaimana cara seorang guru dalam melaksanakan pembelajaran". Oleh karena itu untuk membantu strategi pembelajaran yang aktif, guru dapat menerapkan berbagai metode serta model pembelajaran yang relevan.

Hasil observasi yang dilakukan pada tanggal 25 januari 2017 kelas V SDN Jabung 1 Kecamatan Jabung Kabupaten Malang menunjukkan bahwa hasil belajar IPA rendah, ini dibuktikan dengan nilai rata - rata UTS pada tahun ajaran 2016 - 2017 dibawah KKM yaitu 59.8. Hal ini terjadi karena siswa kurang memiliki literatur belajar, kurang memperbanyak latihan soal yang juga disebabkan karena siswa kurang percaya diri dengan jawaban yang diperoleh antara benar atau salah. Selain itu keberadaan LKS cetak atau yang disebut Lembar Kerja Siswa digunakan sebagai media untuk mengerjakan soal sekaligus sebagai sumber belajar, dan untuk kegiatan percobaan yang ada dalam LKS selalu dilewati dikarenakan untuk mengerjakan kegiatan percobaan tersebut akan menghabiskan waktu pembelajaran.
Akibatnya siswa tidak mengerti sepenuhnya dengan materi yang sedang diajarkan karena mereka tidak meneliti dan melakukan kegiatan percobaan secara langsung, sehingga pada saat mengerjakan soal - soal yang tersedia di setiap kegiatan pembelajaran siswa tidak paham dengan maksud soal tersebut. Akibatnya mereka mengerjakan soal dengan asal - asalan. Dapat dikatakan bahwa penggunaannya masih belum efektif sebagai sarana pembelajaran.

Mengacu pada masalah tersebut, maka diperlukan suatu alternatif pemecahan masalah, salah satu sumber media belajar yang diharapkan untuk meningkatkan kualitas belajar siswa khususnya pada mata pelajaran IPA adalah media LKS berbasis model take and give. Media LKS berbasis model take and give merupakan Lembar Kerja Siswa yang didalamnya mencakup kegiatan pembelajaran yang berbentuk model take and give, dimana LKS berbasis model take and give terdapat sintaks model pembelajaran take and give yang diartikan sebagai memberi dan menerima informasi materi lewat teman sebaya. Diharapkan dengan pemberian LKS pada setiap siswa, dapat leluasa dan memahami materi yang diberikan. Selain itu dengan bersifat model take and give siswa dapat cepat memahami penguasaan materi dan informasi karena mereka memperoleh informasi tidak hanya dari guru akan tetapi dari teman yang lain. Sejalan dengan hal tersebut siswa dan guru dapat menghemat waktu dalam memahamkan informasi materi yang ada.

Mengacu pada hal tersebut peneliti termotivasi untuk mengadakan penelitian guna mengetahui pengaruh media LKS dengan model take and give terhadap hasil belajar IPA. Sehingga judul penelitian yang diangkat oleh penulis yaitu "Pengaruh Media LKS berbasis Model Take and Give terhadap Hasil Belajar IPA Siswa Kelas V SDN Jabung 1 Kecamatan Jabung Kabupaten Malang." Adapun kelas V SDN 1 Jabung ini paralel sehingga peneliti memutuskan bahwa kelas VB sebagai kelompok eksperimen dengan diberi treatment, dan kelas VA sebagai kelompok kontrol.

Pemilihan kelas eksperimen dan kelas kontrol dipilih secara acak menggunakan undian. Setelah 
diobservasi dan menggunakan uji kecocokan kedua kelas relatif sama yaitu jumlah siswa yang berjumlah sekitar 20, untuk kelas VA berjumlah 21 siswa dan kelas VB berjumlah 23 siswa. Berada dilingkungan sekolah yang sama dan tingkat pendidikan kedua guru yang sama yaitu setingkat jenjang S1.

Dari latar belakang yang telah dijabarkan di atas, maka rumusan masalah: (a) Apakah penggunaan media LKS berbasis model take and give berpengaruh pada hasil Belajar IPA siswa kelas V SD Negeri Jabung 1 Kecamatan Jabung Kabupaten Malang; (b) Seberapa besar pengaruh penggunanaan media LKS berbasis model take and give terhadap hasil belajar IPA siswa V SD Negeri Jabung 1 Kecamatan Jabung Kabupaten Malang?

Tujuan dari penelitian ini ialah: Untuk mengetahui pengaruh media LKS dengan model take and give terhadap hasil belajar IPA siswa kelas V SDN Jabung 1 Kecamatan Jabung Kabupaten Malang. Dan untuk mengetahui besar pengaruh penggunanaan media LKS berbasis model take and give terhadap hasil belajar IPA siswa V SD Negeri Jabung 1 Kecamatan Jabung Kabupaten Malang.

\section{KAJIAN PUSTAKA}

Model pembelajaran kooperatif tipe take and give adalah suatu tipe pembelajaran yang mengajak siswa untuk saling berbagi mengenai materi yang disampaikan oleh guru dengan kata lain tipe ini melatih siswa terlibat secara aktif dalam menyampaikan materi yang mereka terima ke teman atau siswa yang lain secara berulang-ulang (Rusmawati, 2009:78). Selain itu juga tipe Take and Give merupakan tipe pembelajaran yang memiliki tujuan untuk membangun suasana belajar yang dinamis, penuh semangat, dan antusiasme, serta menciptakan suasana belajar dari pasif ke aktif, dari jenuh menjadi riang, serta mempermudah siswa untuk mengingat materi.

Tipe Take and Give ini diarahkan agar tujuan belajar dapat dicapai secara efisien dan efektif dalam suasana yang gembira meskipun membahas hal-hal yang sulit dan berat.
Indien (2012) mengungkapkan bahwa model pembelajaran Take And Givemempunyai keunggulan yaitu (1) model pembelajaran ini tidak kaku, karena seorang guru boleh memodifikasi lagi penggunaan model pembelajaran ini sesuai dengan keinginan dan kebutuhan serta situasi pembelajaran, (2) materi akan terarah, karena guru terlebih dahulu menjabarkan uraian materi sebelum dibagikan kartu kepada siswa, (3) melatih siswa untuk bekerja sama dan menghargai kemampuan orang lain, (4)Melatih siswa untuk berinteraksi secara baik dengan teman sekelasnya, (5) akan dapat memperdalam dan mempertajam pengetahuan siswa melalui kartu yang dibagikan kepadanya, sebab mau tidak mau harus menghafal dan paling tidak membaca materi yang diberikan kepadanya, (6)dapat meningkatkan tanggung jawab siswa, sebab masing-masing siswa dimintai pertanggung jawaban atas kartu yang diberikan kepadanya.

Model pembelajaran diperlukan untuk membantu siswa memahami materi dengan melibatkan siswa secara aktif dalam pembelajaran, seperti menugaskan siswa menjadi narasumber dalam kelompoknya. Menurut Hanafiah dan Suhana (2112:40), dalam pembelajaran kooperatif tipe Take and Give ini siswa diajak untuk berfikir dalam menyelesaikan tugas yang telah diberikan oleh guru. Semua siswa dalam kelompok memiliki pembagian sub materi yang berbeda, sehingga memberikan kesempatan kepada masingmasing siswa untuk mempelajari bagian materinya agar dapat menjelaskannya kepada kelompoknya.

Huda (2014: 242-243) langkahlangkah model pembelajaran take and give dapat dilihat sebagai berikut. (1) Guru mempersiapkan kartu yang akan digunakan dalam proses pembelajaran; (2) Guru mendesain kelas sebagaimana mestinya; (3) Guru menjelaskan materi sesuai dengan kompetensi yang ingin dicapai; (4) Untuk memantapkan penguasaan siswa, masing-masing siswa diberi satu kartu untuk dipelajari atau dihafal; (5) Semua siswa disuruh berdiri dan mencari pasangan untuk saling memberi informasi. Tiap siswa harus mencatat nama pasangannya pada kartu 
yang dipegangnya; (6) Demikian seterusnya hingga siswa dapat saling memberi dan menerima materi masingmasing (take and give); (7) Guru mengevaluasi keberhasilan siswa, guru dianjurkan memberi pertanyaan dengan kartu; (8) Strategi ini dapat dimodifikasi sesuai dengan keadaan; (9) Guru menutup pembelajaran.

Kurniasih, dkk. (2015: 103) menjelaskan teknis pelaksanaan model pembelajaran take and give sebagai berikut. (1) Guru menyiapkan kelas sebagaimana mestinya dan menjelaskan tujuan pembelajaran serta menjelaskan model pembelajaran yang akan dilaksanakan; (2) Untuk memantapkan penguasaan siswa akan materi yang sudah dijelaskan, setiap siswa diberikan satu kartu untuk dipelajari (dihafal) selama 5 menit; (3) Kemudian perintahkanlah siswa untuk mencari pasangan untuk saling menginformasikan materi yang telah diterimanya; (4) Tiap siswa harus mencatat nama teman pasangannya pada kartu yang sudah diberikan; (5) Demikian seterusnya sampai semua siswa dapat saling memberi dan menerima materi masingmasing (take and give); (6) Setelah selesai semua, guru mengevaluasi keberhasilan model pembelajaran take and give dengan memberikan siswa pertanyaan yang tidak sesuai dengan kartunya (kartu orang lain); (7) Guru dan siswa bersama-sama membuat kesimpulan mengenai materi yang telah didiskusikan dan setelah itu guru menutup pelajaran.

\section{METODE}

Jenis penelitian ini yaitu
penelitian Sugiyono (2015:107) metode penelitan eksperimen diartikan sebagai metode peneletian yang digunakan untuk mencari pengaruh perlakuan tertentu terhadap yang lain dalam kondisi yang terkendalikan. Metode ini sebagai bagian dari metode kuantitatif mempunyai ciri khas tersendiri, terutama dengan dengan adanya kelompok kontrolnya. Dengan kata lain bahwa penelitian meggunakan pendekatan kuantitatif karena menggunakan data dan statistik.

Desain penelitian yang digunakan adalah true experimental design dengan bentuk posttest-Only Control Design. Dimana dalam desain ini terdapat dua kelompok yang masing - masing dipilih secara random (R). Kelompok pertama diberi perlakuan $(\mathrm{X})$ dan kelompok lain tidak. Kelompok yang diberikan disebut kelompok eksperimen dan kelompok yang tidak diberi perlakuan disebut kelompok kontrol. Pengaruh adanya perlakuan (treatment) adalah $(\mathrm{O} 1: \mathrm{O} 2)$. Dalam penelitian yang sesungguhnya, pengaruh treatment dianalisis dengan uji beda, memakai statistik t-test.

\begin{tabular}{|lll|}
\hline AR & & 02 \\
BR & $X$ & 04 \\
\hline
\end{tabular}

Gambar 1. Posttest Only Control Design
A: Kelompok kontrol
$\mathrm{X}$ : Kelas yang diberi treatment
B: Kelompok eksperimen
O: Posttest
$\mathrm{R}$ : Pemilihan kelas secara random

(Sugiyono,2015)

Penelitian ini dilaksanakan dikelas VA sebagai kelas kontrol dan VB sebagai kelas eksperimen SD Negeri Jabung 1 Jalan Bromo No. 6 Desa Jabung Kecamatan Jabung Kabupaten Malang. Penelitian ini dilaksanakan pada semester 2 pada bulan April 2017.

Menurut Sugiyono (2015:117) Populasi adalah wilayah generalisasi yang terdiri atas objek / subjek yang mempunyai kualitas dan karakteristik yang ditetapkan oleh peneliti untuk dipelajari dan kemudian ditarik kesimpulannya. Yang menjadi populasi dalam penelitian ini adalah seluruh siswa kelas 5 SDN Jabung 1 Kec. Jabung Kab. Malang.

Sampel merupakan sebagian dari jumlah populasi yang dijadikan subyek atau objek penelitian. Teknik pengambilan sampel yakni adalah simple random sampling yaitu pengambilan sampel dengan cara mengambil 1 kelas untuk kelas eksperimen dan yang 1 kelas untuk kelas kontrol. Kelas eksperimen yakni kelas VB dengan 23 siswa, sedangkan untuk kelas kontrol yakni kelas VA dengan 21 siswa. Pemilihan kelas dipilih secara random/acak. Hal ini dikarenakan setelah diobservasi dan menggunakan uji kecocokan kedua kelas relatif sama yaitu jumlah siswa dalam 
satu kelas memiliki jumlah populasi sekitar 20 siswa, untuk kelas VA berjumlah 21 siswa dan kelas VB berjumlah 23 siswa. Berada dilingkungan sekolah yang sama dan tingkat pendidikan kedua guru yang setingkat jenjang S1.

Teknik pengumpulan data berkenaan dengan cara-cara yang digunakan untuk mengumpulkan data (Sugiyono, 2014:193). Dalam penelitian ini cara-cara yang digunakan untuk mengumpulkan data yaitu dengan melakukan tes dan kuesioner.

Tes ialah seperangkat rangsangan (stimuli) yang diberikan kepada seseorang dengan maksud untuk mendapatkan jawaban-jawaban yang dapat dijadikan dasar bagi penetapan skor angka (Furhan, 2004:268) .Tes menurut Suharsimi (2010:150) adalah serentetan pertanyaan atau laihan serta alat lain yang digunkan untuk mengukur keterampilan, pengetahuan intelegensi, kemampuan atau bakat yang dimiliki oleh individu atau kelompok. Dapat disimpulkan bahwa tes merupakan alat ukur kemampuan siswa.

Adapun tes yang dilakukan untuk mengumpulkan data tentang hasil belajar siswa pada ranah kognitif yaitu sebagai berikut: 1) membuat kisi-kisi soal, 2) menyusun soal tes, 3) mengadakan uji coba, 4) dan menganalisis hasil dari uji coba. Kuesioner yang digunakan dalam penilitian ini adalah kuesioner yang berstruktur yakni yang berisi pertanyaanpertanyaan yang disertai dengan pilihan jawaban untuk pertanyaan-pertanyaan tersebut. Jawaban-jawaban yang disediakan bagi setiap pertanyaan hendaknya mencakup semua kemungkinan jawaban serta saling lepas (mutually exclusive), (Arif, 2004:260).

Kuesioner diberikan pada siswa kelas VB sebagai kelas eksperimen setelah diterapkannya LKS berbasis take and give. Diberikannya kuesioner pada siswa bertujuan untuk melihat respon siswa terhadap penggunaan LKS berbasis model take and give, dan guru kelas VA dan kelas VB untuk mengetahui sumber belajar yang digunakan pada saat pembelajaran IPA. Selain itu pelaksanaan dan pemberian skor pada kuesioner hasilnya dapat langsung mengarah kepada analisis yang diteliti.

\section{HASIL DAN PEMBAHASAN}

Deskripsi data menggambarkan tentang data-data dari penelitian yang telah dikumpulkan. Data yang dikumpulkan berasal dari hasil nilai Posttest kelas VA dan VB. Dimana kelas VA sebagai kelompok kontrol yang menggunakan LKS biasa dari penerbit dan kelas VB sebagai kelompok eksperimen yang menggunakan LKS berbasis model Take and Give dengan total jumlah sampel adalah 44 siswa di SD Negeri Jabung 1.

Setelah data diperoleh maka peneliti menganalisis data dengan melakukan uji prasyarat yaitu uji normalitas dan uji homogenitas, uji hipotesis, dan uji regresi untuk mengetahui pengaruh dari penggunaan LKS berbasis model take and give.

Berikut hasil nilai kelas eksperimen Histogram

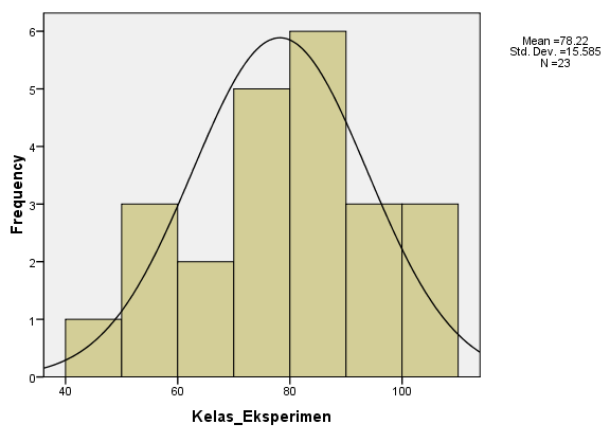

Gambar 2. Histogram Hasil Belajar Kelas Eksperimen

Diketahui bahwa nilai statistik hasil belajar kelas eksperimen menyatakan bahwa besar dari nilai mean adalah 78,22. Nilai median adalah sebesar 84,00. Nilai modus adalah sebesar 84 dan gambar eksperimen terlihat bahwa kecondongan data kelas eksperimen simetris, ini menunjukkan bahwa data eksperimen berdistribusi normal dimana nilai mean $=$ nilai modus . Histogram

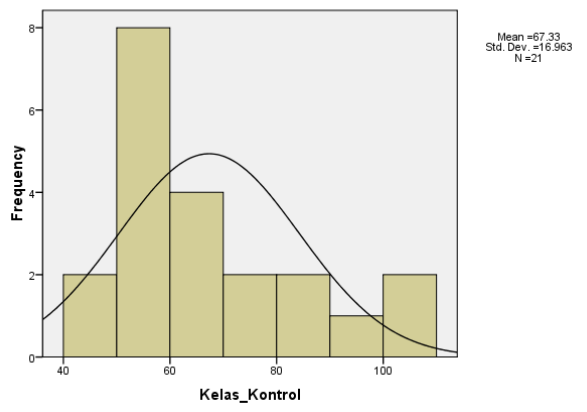

Gambar 3. Histogram hasil belajar kelas kontrol 
Diketahui nilai statistik hasil belajar kelas kontrol menyatakan bahwa besar dari nilai mean adalah 67,33. Nilai median adalah sebesar 67,00. Nilai modus adalah sebesar 59,00 dan histogram gambar kontrol terlihat bahwa kecondongan data kelas kontrol ke arah kanan, ini menunjukkan bahwa data kontrol memiliki condong yang positif dimana nilai mean $>$ nilai modus.

Uji normalitas digunakan untuk mengetahui data berasal dari populasi yang berdistribusi normal atau tidak. Hasil data posttest diuji menggunakan Uji Normalitas Shapiro-Wilk pada SPSS 16.0. Dasar pengambilan keputusan uji Normalitas Shapiro-wilk yaitu jika nilai Sig. > 0,05 maka data berdistribusi normal dan jika nilai Sig. $<0,05$ maka data tidak berdistribusi normal.

Adapun hasil dari uji normalitas shapiro-wilk untuk kelas eksperiman dan kelas kontrol adalah $0,184>0,05$ dan kelas kontrol $0,176>0,05 \quad$ ini menunjukkan bahwa populasi data yang diperoleh berdistribusi normal.

Uji homogenitas dilakukan untuk mengetahui variansi dari kedua populasi. Peneliti menguji variansi nilai hasil belajar dari kelas eksperimen dan kontrol. Pengujian dilakukan pada SPSS 16.0. Hasil keputusan uji homogenitas yaitu nilai Sig $>0,05$.

Adapun hasil uji homogenitas dari kelas eksperimen dan kelas kontrol adalah $0,0757>0.05$ ini menunjukkan bahwa kedua kelas memiliki varian nilai yang sama atau homogen.

Uji hipotesis dilakukan setelah uji prasayarat yakni uji normalitas dan uji homogenitas terpenuhi. Uji hipotesis yang digunakan adalah uji-t pada SPSS 16.0 .

Uji-t digunakan untuk mengetahui pengaruh hasil belajar siswa kelas eksperimen yang menggunakan LKS berbasis model take and give dengan hasil belajar siswa kelas kontrol yang menggunakan LKS biasa. Keputusan diambil berdasarkan pada ketentuan uji hipotesis, yaitu nilai Sig.(2-tailed) >0,05, maka Ho diterima dan $\mathrm{Ha}$ ditolak, atau sebaliknya nilai Sig.(2-tailed) $<0,05$, maka Ho ditolak dan Ha diterima.

Adapun hasil Uji Hipotesis Beda Rata (T-tes) dari kedua kelas adalah $0.032<0,05$. Sesuai dengan Sig. (2- tailed) yang dihasilkan maka dinyatakan bahwa Ho ditolak dan Ha diterima. Sehingga dapat disimpulkan bahwa LKS berbasis model take and give berpengaruh terhadap hasil belajar IPA siswa kelas V SD Negeri Jabung 1 Kec. Jabung Kab. Malang.

Dalam mencari besar pengaruh media LKS berbasis model take and give yang digunakan oleh kelas eksperimen, maka peneliti menggunakan uji regresi linier pada SPSS 16.0. Dalam hal ini, variabel yang menggunakan uji regresi yaitu hasil nilai tugas yang diberikan pada LKS berbasis model take and give sebagai variabel bebas $(\mathrm{X})$ dengan hasil nilai posttest yang dijadikan sebagai variabel terikat $(\mathrm{Y})$.

Adapun hasil dari besar pengaruh penggunaan LKS berbasis model take and give adalah sebesar 0,479. Artinya penggunaan LKS berbasis model take and give memberikan pengaruh sebesar $0,479(0,479 \times 100 \%=47,9 \%)$ atau memberikan kontribusi sebesar 47,9\%terhadap hasil belajar, sedangkan $52,1 \%$ dijelaskan oleh variabel lain diluar penelitian.

Berdasarkan hasil dari uji prasyarat dan uji hipotesis, maka LKS berbasis model take and give berpengaruh terhadap hasil belajar IPA siswa kelas V. Penggunaan LKS berbasis model take and give pada kelas eksperimen mememberi pengaruh yang cukup signifikan sebesar 0,032 dengan LKS biasa yang digunakan oleh kelas kontrol yang dapat disimpulkan bahwa Ho ditolak dan Ha diterima. Nilai dapat dilihat pada tabel 4.11 Hasil T-tes Sig.(2tailed).

Selain itu besar pengaruh penggunaan LKS berbasis model take and give terhadap hasil belajar adalah sebesar 47,9\%. Meningkatnya hasil belajar IPA siswa kelas VB sebagai kelas eksperimen dikarenakan belajar menggunakan LKS berbasis model take and give menuntut siswa untuk mengingat dan menghafal materi dengan baik, selain itu dapat melatih siswa untuk menjadi narasumber dan mitra belajar yang baik bagi teman-temannya dengan saling bertukar informasi yang dimiliki. Hal ini sejalan dengan Silberman (2010:175) yang menyatakan bahwa mengajar teman sebaya memberikan 
kesempatan kepada peserta didik untuk mempelajari sesuatu yang baik pada saat yang sama saat ia menjadi narasumber yang lain.

Hasil yang ditemukan peneliti pada saat proses pembelajaran menggunakan LKS berbasis model take and give yaitu masing-masing siswa dalam satu kelompok mempunyai tanggung jawab untuk mengerti dan mengahafal terhadap materi yang dimiliki karena masingmasing anggota kelompok mempunyai materi yang berbeda-beda sehingga tidak ada anggota kelompok yang pasif, suasana belajar menjadi interaktif, materi yang didapatkan ringkas dan mudah difahami karena penyampaian informasi materi didapatkan dari teman sebaya, dan pada saat mengerjakan soal evaluasi mereka cenderung mandiri. Hal ini sejalan dengan tujuan penyusunan LKS menurut Andi (2013:206) yang menyatakan bahwa LKS memudahkan guru dalam memberikan tugas kepada siswa, memudahkan siswa untuk berinteraksi dengan materi yang diberikan, menyajikan tugas-tugas yang dapat meningkatkan penguasaan siswa terhadap materi yang diberikan dan melatih kemandirian siswa.

Berdasarkan kuesioner respon siswa tentang penggunaan LKS berbasis model take and give, siswa memberikan respon positif selama proses pembelajaran menggunakan LKS berbasis model take and give. Adapun hasil presentase dari butir instrumen yang dihasilkan adalah sebagai berikut sebanyak $73,9 \%$ siswa faham dengan baik materi yang tersedia dalam LKS berbasis model take and give, sebanyak $82,6 \%$ respon siswa dalam meminati LKS berbasis model take and give dikategorikan sangat baik, sebanyak $52,2 \%$ siswa tidak mengalami hambatan dalam menggunakan LKS berbasis model take and give yang dikategorikan cukup baik, sebanyak $65,2 \%$ respon siswa dalam menyukai tampilan LKS berbasis model take and give dikategorikan cukup baik, sebanyak $91,3 \%$ siswa sangat meminati proses pembelajaran IPA dengan menggunakan LKS berbasis model take and give atau dikategorikan sangat baik. Sehingga dapat disimpulkan bahwa rata-rata persentase yang didapatkan dari instrumen kuesioner tentang respon siswa terhadap LKS berbasis model take and give adalah sebesar 73,04\% dalam kategori baik.

Berdasarkan penjelasan diatas, maka LKS berbasis model take and give berpengaruh terhadap hasil belajar IPA. Hal itu dibuktikan dengan meningkatnya nilai rata- rata yaitu sebesar 78,22 pada siswa kelas eksperimen. Peningkatan tersebut lebih tinggi dibandingkan kelas kontrol dengan nilai rata-rata 67,81 yang menggunakan LKS biasa.

Hal ini sejalan dengan penelitian skripsi yang dilakukan oleh Hidayat pada tahun 2014 dengan judul "Pengaruh Penggunaan Lembar Kerja Siswa Berbasis Model Problem Solving Polya pada Konsep Fluida Dinamis terhadap Kemampuan Menganalisis Siswa di SMA Negeri 7 Kota Tanggerang Selatan" yang menjelaskan bahwa secara umum LKS berbasis Problem Solving Polya memberikan efek positif terhadap pembelajaran fisika, hal tersebut didukung oleh hasil uji hipotesis nilai posttest, dimana nilai $\mathrm{t}_{\text {hitung }}$ yaitu $\mathrm{t}_{\text {tabel }}$ yaitu 5,31 $>2,00$ karena nilai $t_{\text {hitung }}>t_{\text {tabel }}$ yang dapat disimpulkan bahwa $\mathrm{H}_{1}$ diterima dan $\mathrm{H}_{\mathrm{o}}$ ditolak, yang artinya terdapat pengaruh penggunaan LKS berbasis problem solving Polya dalam konsep fluida dinamis terhadap kemampuan menganalisis siswa.

Sehingga dapat disimpulkan bahwa LKS berbasis model take and give berpengaruh terhadap hasil belajar IPA siswa kelas V. Peningkatan nilai yang dihasilkan tidak terlepas dari respon positif siswa tentang penggunaan LKS berbasis model take and give.

\section{SIMPULAN}

Berdasarkan hasil penelitian yang telah dilakukan, dapat disimpulkan bahwa: (a) LKS berbasis model take and give berpengaruh terhadap hasil belajar IPA siswa kelas V SD Negeri Jabung 1. Hal ini dibuktikan dengan nilai nilai ratarata yang didapatkan pada kelas eksperimen adalah 78,22 sedangkan untuk kelas kontrol mendapatkan nilai rata-rata sebesar 67,33 dengan Sig.(2tailed) pada uji hipotesis adalah sebesar 0,032 yang artinya nilai tersebut kurang dari 0,05 dengan taraf kepercayaan sebesar 95\%; (b) besar pengaruh 
penggunaan LKS berbasis model take and give terhadap hasil belajar IPA siswa kelas V SD Negeri Jabung 1 Kec. Jabung Kab. Malang memberikan kontribusi sebesar $\quad 47,9 \%$ sedangkan $52,1 \%$ dijelaskan oleh variabel lain diluar penelitian.

Berdasarkan temuan selama penelitian, maka saran yang diberikan untuk penelitian selanjutnya yaitu LKS berbasis model take and give yang telah dibuat perlu dilakukan tahap validasi kepada ahli pembelajaran, sebelum menggunakan LKS berbasis model take and give sebaiknya siswa diminta untuk membaca dengan baik tentang cara menggunakan LKS tersebut agar tidak membingungkan siswa, dapat mengembangkan lebih lanjut penelitian tentang pengaruh LKS berbasis model take and give dengan menambahkan variabel bebas lainya seperti minat, motivasi ataupun prestasi maka ruang lingkup penelitian lebih luas, LKS berbasis model take and give diharapkan dapat diterapkan tidak hanya pada mata pelajaran IPA saja akan tetapi dapat diterapkan pada mata pelajaran yang lain, LKS berbasis model take and give diharapkan dapat diiteliti dengan menggunakan jenis penelitian kualitatif pengembangan.

\section{DAFTAR PUSTAKA}

Arikunto, Suharsimi. 2010. Prosedur Penelitian Suatu Pendekatan Praktik. Jakarta: Rineka Cipta.

Depdiknas.2006. Kurikulum Tingkat Satuan Pendidikan (KTSP). Jakarta:Departemen Pendidikan Nasional.

Furchan, Arief. 2004. Pengantar Penelitian dalam Pendidikan. Yogyakarta: PUSTAKA BELAJAR.

Hamzah dan Nurdin, 2011. Belajar dengan Pendekatan P.A.I.L.K.E.M. Jakarta: PT Bumi Aksara.

Hanafiah, N. dan Suhana, C. 2009. Konsep Strategi Pembelajaran. Refika Aditama. Bandung.
Hidayat, Taufik. 2014.Pengaruh

Penggunaan Lembar Kerja Siswa

Berbasis Model Problem Solving

Polya pada Konsep

FluidaDinamis terhadap

Kemampuan Menganalisis Siswa di SMA Negeri 7 Kota

Tanggerang Selatan. Skripsi tidak diterbitkan: Universitas Islam

Negeri Syarif Hidyatullah Jakarta.

Kurniasaih, Imas, dkk. 2015. Ragam

Pengembangan Model

Pembelajaran. Jakarta: Kata

Pena.

Martinis Yamin dan Bansu I. Ansari. 2009. Taktik Mengembangkan Kemampuan Individual Siswa. Jakarta: Gaung Persada Press.

Huda, Miftahul. 2014. Model-model Pengajaran dan Pembelajaran. Yogyakarta: Pustaka Pelajar.

Prastowo, Andi. 2013. Panduan Kreatif Membuat Bahan Ajar Inovatif. Yogyakarta: Diva Press.

Rusmawati, Dede. 2009. Perbedaan Hasil Belajar Siswa yang Proses Pembelajarannya Menggunakan Model Kooperatif tipe Take and Give dengan tipe Make a Match pada sub Konsep Alat Indra Manusia. Skripsi: Tasikmalaya: UNSIL.

Sanjaya, Wina. 2009. Strategi Pembelajaran Berorientasi StandarProses Pendidikan. Jakarta: Prenada.

Silberman, Mel. 2010. 101 Cara Pelatihan dan Pembelajaran Aktif. Terjemahan Dani Dharyani. 101 Ways to Make Training Active.2005. Jakarta: Indeks.

Sugiyono. 2015. Penelitian Pendidikan Pendekatan Kuantitatif, Kualitatif, dan $R \& D$. Bandung: Alfa Beta. 